\title{
The Physics of Metaphysics
}

\section{The Technique of Ghost Apparition in Gryphius' Catharina von Georgien and Carolus Stuardus}

\begin{abstract}
The first objective of the article $^{1}$ is to illustrate that the ghosts in Gryphius' Catharina von Georgien and Carolus Stuardus are, unlike what is claimed in Luther's theology, neither the devil himself nor the work of the devil but rather the mouthpiece of the divine spirit. They thus have the task of delivering the highest metaphysical truths. In order to stage the ghost apparitions, Gryphius - and illustrating this is the second objective of argument in the text draws from the entire technical repertoire of the German Baroque stage. While in the course of the scenes without ghosts only one characteristic element of the Baroque stage is used, namely the quick conversion of the periaktos on a perspectivized stage, all of the other 'highlights' of the Baroque stage, especially the use of light and flying machines, as well as lifting and lowering mechanisms, are reserved for the scenes containing ghosts and spirits. The third part of the article shows that these new techniques of stagecraft are based on contemporary practical physics, and in this case on mechanics and optics, with which Baroque dramatic literature, in the course of its self-constitution, conducts a type of performative dialogue.
\end{abstract}

\section{Imitatio Christi}

It has repeatedly been pointed out ${ }^{2}$ that Gryphius' dramas Catharina von Georgien (created in 1647, first print 1657) and Carolus Stuardus (created in 1649/50 [A]/1660? [B]; first print 1657 [A]/1663 [B] $)^{3}$ are very similar: they are often mentioned in the same breath. ${ }^{4}$ In both cases, a sovereign is hindered in executing

1 The complete article was translated from the German by Sandra Evans.

2 Cf. the explanation of Mannack as editor in Gryphius 1991, 1095. In accordance with this edition, citations in the following will be cited under Sigle D.

3 I will cite in line with the B version. On the creation of the A and B versions and the different sources that Gryphius used for these versions, cf. Schönle 1933; Berghaus 1984; Habersetzer 1985, 17-18 and 23-38; Stackhouse 1986, 89-95.

4 Cf. for instance Kaminski 1998, 98-121, which discusses the plays in one chapter due to their similarities in topic. 
his authority, and even threatened with death, as a result of the confrontation with a second power. For Catharina this second power is the Persian ruler Shah Abbas, and for Carolus it is Cromwell and the movement of Independents. In the end both rulers will suffer death as martyrs (cf. Steinhagen 1977, 299-302; Parente 1987, 186-208). They are able to face death and, in Catharina's case, stare the preceding torture straight in the eye because they trust in Christ and, what is more, perform the imitation of Christ ${ }^{5}$ and consequently replicate his passion. As a result of being so close to and even identifying with Christ, they attain a strength that enables them to overcome the fear of pain and death.

However, the plays are not so similar that the imitation of Christ would be organized in the exact same way. For Catharina, her situation is that she is a prisoner of Shah Abbas, who covets her and wants her to become his wife. If she were to accept his proposal, she would be free on the outside and possess a kingdom; however, in order to do so, she would have to give up her inner freedom: ${ }^{6}$ her religion and her loyalty toward her husband even after his death (cf. Szarota 1976, 71).

Now, if Catharina were to reject Shah Abbas's proposal, she would have to be well aware of the likelihood that she will soon suffer torture and then death. As Schings (cf. 1968, 57-68) has shown, she is able to bear the prospect of impending attacks on her body by invoking a stoicism in which the spirit withdraws from the body that is or will be maltreated. This becomes obvious as she, in reference to her role as queen, shouts the central sentence of the stoic doctrine at Salome: "Regire dein Gemütt” (D 190, V. 72).

We find this analogization of ruling the kingdom with self-control of emotions, or in other words the transfer of sovereignty into one's psyche, as early

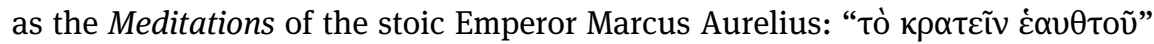
(I, 15; "mastery of self;" Marcus Aurelius 1944, 10-11). This turning back toward the inner life in Marcus Aurelius's text leads to a devaluation of the outer realm,

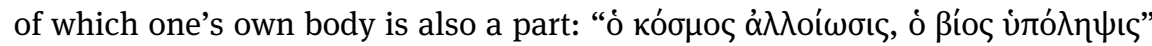
("The Universe is change, life is opinion;" Marcus Aurelius 1944, 50 and 53). Catharina also thinks this way; in the words of the priest who speaks about her after her martyrdom: "Diß Thraenenthal / die Erd | Diß Angsthauß war nicht mehr des grossen Geistes werth” (D 213, v. 179-180).

5 Cf. with respect to Carolus the analysis in Niefanger 2005, 164-170. With recourse to Habersetzer 1985, 37-38, Niefanger provides evidence that the figure of thought of Karl's Imitatio Christi originates from the "royalistischen Seite des historischen Diskurses der Zeit" (169). Cf. also Grimm 1986, 6-7.

6 On the ambiguity of freedom and imprisonment in Catharina, cf. Feger 1997, 94 et passim. 
Furthermore, Catharina considers herself to be a sponsa Christi, something also established by Schings (cf. 1968, 69-72). This is in two ways a logical response to the decision with which Shah Abbas confronts her. First of all, by marrying a heathen Catharina would, from a Catholic perspective, violate the "überaus enge Vereinigung Christi und der Kirche” [“Arctissima Christi et Ecclesiae [...] coniunctio”], which symbolizes marriage as such (Buse 1867, 310; cf. Rieks 1996, 23-135). Moreover, from a Protestant perspective, ${ }^{7}$ her bond with God through marriage, which indicates that people are "ynn sunden empfangen und geporn," although each sin implicit in sexuality is "verschonet" (Luther 1907, 304) by God, would be destroyed and she would thus be thrust into sin. Hence Catharina clearly understands that with his marriage proposal the heathen Shah Abbas would replace not only her husband, but also the one who created this matrimony, namely the Christian God (cf. Bergengruen 2013).

Second, in love mysticism it is the female soul which unites with the male lover, i.e., Jesus Christ, in the act of mystical union. As is well known, it is Bernard of Clairvaux (1090-1153) who in his sermons fixes and canonizes the tradition of interpretation according to which the expected union of the lovers, as described in the Song of Songs, should be understood allegorically as a union of the soul (anima, female) with God (male). ${ }^{8}$ Gryphius, however, does not directly refer to this tradition, but rather to its specifically Protestant reception. ${ }^{9}$ Thus Catharina follows the anti-corporeal stoicism that she has also invoked, as mentioned above. As a martyr with a maltreated body, and with her impending death, she cannot count on her body, but only her soul. It is only this that will later unite with the heavenly groom.

Now, as regards Carolus Stuardus: the imitation of Christ as a figure of thought has been referred to many a time in the research literature. ${ }^{10}$ Yet the meaning developed here is slightly more differentiated: namely, the notion of the two bodies of the king is actually invoked beyond that in different places in

7 As a representative of the Caucasian Eastern Church with respect to confession, Catharina is something like a blank space or a projection plane for Gryphius.

8 Cf. the Song of Songs tradition of interpretation of spiritual wedlock (instead of wedlock in church), especially in Bernard of Clairvaux, Ruh 1990, 253ff. (with a reference to the foundational work conducted by Ohly 1958, 135ff.), as well as McGinn 1996, $280 \mathrm{ff}$.

9 Cf. Loos 1999, 698-716. The reference to the Protestant tradition of a Unio mystica reinforces a fundamental tendency in recent research, within the framework of which Gryphius' Protestant disposition is increasingly emphasized despite his taking on Catholic motifs. Cf. in general Tarot 1987, 226-231; Borgstedt 1999, 563-565 (similarly, Borgstedt 2000, 48-49); Bogner 1999. 10 See Schöne 1968, 167-169, with a focus on the thought of the figuration or post-figuration; as well as Habersetzer 1985, 21-24 and 35-36. On the political dimension of the martyr dramas, cf. Spellerberg 1996, 442-44, and Streller 1993, 110-118, particularly, however, Campe 2000, 283-287. 
the drama. However, this notion is understood not in the sense that the physical body stands for the mystical body of the king, but rather in the sense that when the physical body dies (and this is what Carolus Stuardus assumes), the mystical one will continue to exist:

Jch muß die Trauer-Post an Freund' und Kinder schicken
Daß Carl itzund vergeh'. Nein! kan der untergehn
Der zu der Crone geht! der feste Carl wird stehn /
Wenn nun sein Coerper faellt / der Glantz der Eitelkeiten /
Der Erden leere Pracht / die strenge Noth der Zeiten
Vnd diß was sterblich heist / wird auff den Schauplatz gehn /
Was unser eigen ist wird ewig mit uns stehn[.]

(D 519, v. 42-48)

That which will be killed, according to the argumentative logic of Carolus, is merely the external body of the body, which essentially belongs to the "Glantz der Eitelkeiten," to the "Erden leere[r] Pracht” etc. Karl's remarks differ from pure Vanitas imagery in that he not only considers immortality to be a "Selen schatz," as the famous sonnet by Gryphius $(1963,48)$ claims, but also that it is the crown, i.e., the sign of his sovereignty.

The "corona [...] invisibilis" (Kantorowicz 1997, 336) mentioned here represents the corpus mysticum of the empire ruled by Karl. In essence, the argument is that the king is in fact more than merely his physical body. Through the crown he wears, he is guaranteed to live on as a representative of his empire and of Christ after he dies. The mystical body of the king, the mystical crown and the mystical kingdom cannot be harmed by the physical death of the ruler.

Kantorowicz pointed out that the notion of the mystical body of the empire is a politicization of a theological theory. The corpus reipublicae mysticum is the legal successor of the corpus ecclesiae mysticum (cf. Kantorowicz 1997, 194-196 and 207). Originally, however, the notion of the mystical body is valid for all of humanity. In this case, accordingly, it is not the mystical body of the church that is indicated, but rather the body of Jesus Christ.

The notion of the mystical body of Christ, in which all believers, maybe even all persons and possibly even all creatures, are able to partake, is developed in different places in Pauline theology (e.g., 1 Corinthians 6:15, 12:12, 12:18, Romans 12:5 etc.) and is an elaboration of the idea of the state as an organism, a figure of thought already cultivated by Plato and Aristotle. ${ }^{11}$ This figure of thought is referred to prominently in Neoplatonic Patristics, for instance by Gregory of Nyssa in Oratio chatechetica magna (cf. here Bergengruen 2006).

11 Cf. here the still valuable article by Nestle 1927, 350-360. 
Karl of course knows that the notion of the king' mystical body goes back to the notion of the mystical body of Jesus Christ. In this respect he deliberately calls for an imitation of Christ if he himself lays claim to "Der Ewikeiten Cron" (D 545, v. 448), which goes beyond the purely political dimension, in that he makes an analogy between his death and the Passion. Carolus Stuardus is a successor of Christ not only qua royal dignity, but also because he, just like Catharina von Georgien (and also Leo Armenius in the play of the same name), does not eschew the death intended for him, but carries his cross and follows Jesus.

\section{Dreams and spirits: Theory}

It is striking that those crowned heads who succeed Christ have contact with him in ways not restricted solely to quiet prayer. From the theater's viewpoint, this might result from the fact that this form of dialog is not very meaningful. Gryphius, who very much conceives his plays with actual production in mind (cf. here Flemming 1921, 165), accordingly provides for an entirely different form of communication.

In the preface to Carolus Stuardus he writes in reference to Petronius's Satyricon $(118,6)$ :

Freilich gilt hier mit Sicherheit jenes Diktum Petrons: "Historische Tatsachen sind nicht einfach in Verse zu bringen, weil das die Historiker weit besser machen, sondern durch Retardierung und Verwendung mythologischer Figuren" - dazu füge noch Geistererscheinungen und Masken [correct: Geister- und Gespenstererscheinungen] - "und die sentenziöse Prägnanz des Stils erscheint der poetische Geist, damit eher die Weissagung eines Rasenden offenbar werde als ein religiöses Vertrauen durch Zeugnisse einer Rede."12

(D 1102, v. 13-21; added by MB)

12 In the original Gryphius writes: “'Non res gestæ versibus comprehendendæ sunt, qvod longe melius historici faciunt: sed per ambages, Deorum,' adde \& spectrorum, Larvarumq; 'ministeria, et fabulosum sententiarum tormentum præcipitandus est liber spiritus, ut potius furentis animi Vaticinatio appareat, qvam religiosæ orationis sub testibus fides"' (D 446). This section in Petronius's text reads: "non enim res gestae versibus comprehendendae sunt, quod longe melius historici faciunt, sed per ambages deorumque ministeria et fabulosum sententiarum tormentum praecipitandus est liber spiritus, ut potius furentis animi vaticinatio appareat quam religiosae orationis sub testibus fides" - "Historical events are not to be treated in verses, for historians handle such material far better. The free spirit of genius should plunge headlong into oracular utterances, the succor lent by the gods, and the Procrustean control of lapidary phrases; the result should appear as prophetic frenzy rather than as a trustworthy, scrupulous 
What is remarkable here is not only the citation selected by Gryphius, but also the amendment he added. Let us begin with Petronius's theory of the theater, which assumes that that which is presented at the theater needs to neither historically nor legally be safeguarded. It is much more significant that the speech contains a theatrical dimension, for instance when it concerns the "Weissagung eines Rasenden” or a vision. So much for Petronius.

Gryphius, however, goes one step further when he weaves his own amendment into Petronius's citation ("dazu füge noch Geistererscheinungen und Masken [correct: Geister- und Gespenstererscheinungen]") and thus also considers the apparition of ghosts a necessary theatrical presentation which is separated from pure historicity. This last addition is not completely unproblematic. The genre might allow for it, but theologically it contains a few pitfalls, at least for a Lutheran such as Gryphius.

What is an apparition of a spirit or a ghost, in reality? According to Lutheran orthodoxy it is none other than the "Teufel" himself, who "des Nachts" is responsible for the appearance of "Gespenst vnd Poltergeister" (Porta 1591, Bl. 328r). The Lutheran stance evolved from its strong belief in the devil on the one hand, and on the other from its dissociation from the Catholic position, which insists that purgatory exists and consequently considers ghosts to be either demons, or rather animae damnatae, or animae purgandae, i.e., damned persons or souls in purgatory that appear to humans in order to scare them or to plead for their own redemption (Schott 1667, 292). ${ }^{13}$

Let us, however, keep our focus on Gryphius: his insistence on ghosts and spirits being an elemental part of the theatrical plot is not consistent with Protestant doctrine because according to Luther the words of spirits or ghosts are the keenest of competition to the divine word: "Gott wils nicht haben / das du von den Todten lernen / vnd Wahrheit forschen solt." Man should not listen to the word of the evil spirits but "auff Gottes Wort" (Porta 1591, Bl. 329v) alone. Gryphius thus placed himself in a self-made dilemma: the genre of the drama as such and the technical possibilities of performance in practice - something I will talk about later - support the apparition of ghosts; theology, however, does not allow it.

Gryphius is very well aware of the fact that he is caught in this dilemma. In the preface to Leo Armenius he feels obliged to defend the "Träume / Gesichter / frembde Bilder" (D 11-12, v. 29-30), and in the preface to Cardenio und Celinde he

account attested by witnesses” (Petronius 2003, 129f; Petronius 1996, 113). My translation tries to highlight Gryphius' reading of the passage.

13 See also Rieger 2011, 39-47; Neuber 2005, 31-32; as well as Mahlmann-Bauer 2004, 124-125. 
defends the appearance of "Gespenster und Erscheinungen” (D 235, v. 2), i.e., exactly those two elements he, with Petronius beyond, considers to be especially important for the theatrical performance in comparison to the historical one.

The argument accompanying the apologia is divided into two parts. Firstly, Gryphius underlines the metaphysical truth of visions and apparitions. With respect to ghosts he refers to his treatise called De spectris, which was still to be published at that point in time (which was, however, never actually released), when he emphasizes that he will prove at a "besonderen Ort" that the ghosts and spirits are not merely "Mährlin oder traurige Einbildungen" (D 235, v. 3).

Secondly, concerning visions, he also maintained that one should not consider them "für gantz eitel" (D 12, v. 10) - irrespective of whether they appear in a literary or in a historical text. Beyond that, he argues (with Petronius and of course Aristotle, Poetics 1451) that completely different rules apply to a literary, and to be more precise to a dramatic text, and specifically for visions and apparitions. In the preface to Cardenio und Celinde Gryphius emphasizes that this play is a "Gedicht[]" (D 235, v. 6). What this in turn means he has already elaborated on in the preface to Leo, where he admits that he allowed a little "Freyheit" "auff diesem Schauplatz" for the "Dichtkunst” (D 12, v. 28-30).

One must interpret this to mean that in the field of dramatic poetry another form of theology - or better, another form of discourse on and confirmation of theology - prevails. The strict Lutheran rules, which maintain that only the devil can be involved in apparitions, are revoked. However, the purpose of this difference is not to question the Lutheran confession as a whole, but quite the opposite: to affirm it using the methods of the theater.

The ghosts in Leo and in Cardenio do not speak for themselves (not even the evil ones among them); rather they utter nothing less than the word of God. In fact, the very same word of God which competes in Lutheran theory beyond the theater with the words of ghosts, can coincide with them, and even act as verification on (the theatrical) stage.

\section{Dreams and spirits: Practice}

So much for theory. Let us now look at the visions and apparitions of ghosts in both plays. In the case of Catharina von Georgien it is quite easy. There is actually only one ghost: the protagonist herself. Catharina appears to her lover and antagonist Shah Abbas at the end of the drama exactly at the moment he feels remorseful about the murder ("bringt die Mörder umb / die Hand an sie geleget! | Weg Zepter weg! Chach hat hir selber Schuld!”) and wants to kill 
himself: "Komm komm mein Schwerdt! wir haben Macht uns selbst zu straffen!" (D 221, v. 417-418, 421).

As Shah Abbas sees her, he is not sure whether this is an apparition or a fantasy: "Wie? oder schreckt uns eitel Phantasy!” (D 222, v. 427). However, whatever Catharina is, she delivers a kind of prophecy with respect to the downfall of Shah Abbas:

Dein Lorberkrantz verwelckt! dein sigen hat ein Ende.

Dein hoher Ruhm verschwindt! der Tod streckt schon die Haende

Nach dem verdamten Kopff. Doch eh'r du wirst vergehn;

Must du dein Persen sehn in Kriges Flammen stehn /

Dein Hauß durch schwartze Gifft der Zweytracht angestecket /

$\mathrm{Bi}$ du durch Kinder-Mord und Nechstes Blutt beflecket

Feind / Freunden und dir selbst untraeglich / wirst das Leben

Nach grauser Seuchen Angst dem Richter uebergeben.

(D 222, v. 433-440)

This ghostly appearance corresponds very closely to a vision ${ }^{14}$ that haunts Catharina from the beginning to the end of the play. Here, not only does she consider the ascent to the throne offered by Shah Abbas a prefiguration of her future torture; what is more, the torture is closely analogous to Christ's way of the cross. This becomes obvious to her with the imagined crowning especially:

Daß die besteinte Cron die mich vor disem schmueckte

Diß mein geaengstet Haupt mehr als gewoehnlich drueckte;

Biß mir das klare Blut von beyden Schlaeffen lif /

Vnd ich an statt der Cron nur Rosen-Aest ergriff /

Verdorrte Rosen-Aest / die als ein Krantz gewunden

Fest umb die Stirn gedruckt auff meinen Haren stunden.

(D 136-137, v. 333-338)

Before she is then actually tortured, in the last citation she once more makes the implicitly mentioned reference to Jesus Christ explicit: "Schaut JEsus geht voran! ein Augenblick beschwert / | Die Ewikeit erquickt. Creutz / Messer / Zang' und Herdt | Sind Staffeln zu der Ehr'. Jtzt wird der Traum erfuellet” (D 200 , v. 351-353). From this it is revealed that the last two visions are interconnected, which specifically emphasizes the christological moment. Through the consequent union with Christ via torture, Catharina is ultimately able to appear to Shah Abbas as a ghost, who makes a prophecy which does not deviate from

14 Even though they have the form of a dream, it is important to distinguish visions from simple uses of the motif of the dream in the Baroque drama (see Borgstedt 1999, 574-575). 
the word of god one bit God at all. This spirit thus in no way comes from the devil, but is much more a figuration of (almost) pure divine speech.

Things get a bit more difficult in Carolus Stuardus. The topic of dreams/visions does not play a particularly important role here, at least not for Karl, who does not have the impulses that Catharina had. Instead, however, - at least in the B-version, which I am analyzing - there are considerably more apparitions of ghosts. The second Abhandlung starts with the appearance of Stafford's and Laud's ghosts and later on the ghost of Maria Stuart also appears. The former are Karl's two most important advisors, whom he had to have executed.

These two did not come in order to take revenge on Karl. They are very well aware of the fact that the English king acted solely in response to the pressure exerted by Parliament. Their intent was to point out the injustice now befalling Karl:

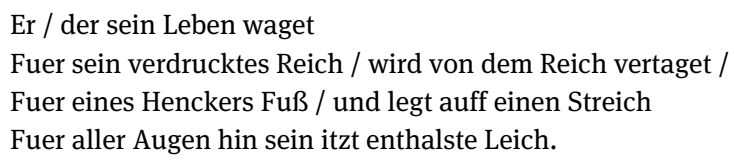

(D 474, v. 237-240)

Most of all, however, both of the former advisors to Karl make a prophecy to the English people ("Weh! Weh! muß denn mein Geist sich wittern | Vnd dein MordProphete seyn?” D 470, v. 121-122), that it will soon spill the same blood as Karl did: "Das gantze Land ist voll / | Voll Volck / das bald dein [Karls] Blut mit Blut aussöhnen soll” (D 474, v. 251-252). This prophecy is again taken up in the fifth Abhandlung as Poleh in his madness has a vision in connection to which the injustice of this act, like the acts of the ghosts of those who passed away in the second Abhandlung, becomes obvious to him. ("Du [Karl] stirbst ohn Schuld; und ich leb' allem Recht zu wider!” D 535, v. 161). And within the framework of this vision the prophecy from the second Abhandlung also becomes more concrete: what will be shown is the "Virtheilung des Hugo Peters und Hewleds" (D 536), the dead body of "Cromwels" and his combatants (D 537), and most of all, "wie der Bischoff / Carlen den II. krönet” (D 538).

This also clarifies that in this play too, all ghosts speak one language, namely in that she foretell divine judgement, which will come into being in English politics in the years following Karl's death. This is also and especially true for the ghosts and characters of the visions. They do not speak in their own names either, it is rather God who speaks from inside them and through them. 


\section{Dreams and spirits: Technique}

Let us now look at how the scenes with spirits are conceived technically, beginning with Carolus Stuardus. Remarkably, in this drama there are hardly any didascalia. Nevertheless, as is the case in Catharina (see below), we can assume a Telari-based transformation stage, as three stylized stage sets alternate, which frame the different figure groupings: Carolus and entourage, Cromwell and entourage, Fairfex and his wife. From this normal form of the transformation stage, the scenes with spirits are now able to come to the fore by an increased use of theater techniques. In order to reconstruct this I will start with the scene containing spirits in the fifth Abhandlung.

Via stage direction, Gryphius clearly states how he imagines the ghostly future events, i.e. the killing of the Independents, to occur:

Vnter disen Worten oeffnet sich der innere Schau-Platz / [...] Der Schau-platz schleust sich. (D 536) / Der Schau-platz oeffnet sich zu dem andernmal / [...] Der Schau-platz schleust sich. (D 537) / Der Schau-platz oeffnet sich zu dem drittenmal / [...] Der Schau-platz schleust sich. (D 538)

In a strict sense, only a curtain, and not a setting can open and close - and this is arguably exactly what Gryphius intended: in the three cases mentioned the rear stage is opened using light and the rear stage curtain ("Schauplatz"). This is where the ghosts enter and exit the stage. And since this takes place far enough away from the audience, it is likely that no further technical aids are necessary to depict the killing of the Independents and the crowning of Karl II as an apparition of ghosts. The last stage direction reveals that this is such an apparition: "Die Geister verschwinden" (D 539; emphasis by MB).

Even in the first apparition of ghosts, in the scene where both former advisors of Karl appear in the second Abhandlung, Gryphius chooses to use the device of two stage halves. In this case the act begins with a ghost scene, most probably at the rear of the stage, and after a certain point in time an increase in light makes the front of the stage more visible. As the ghost of Maria Stuart appears after the ghosts of both advisors have appeared, Karl is actually also present and in fact "auff dem Bette" (D 471). One can assume that Gryphius imagined the scene in such a way that the first two ghosts appear at the back of the stage while the front of the stage is still dark. When Karl and Maria then appear together in the next scene, the front of the stage is also illuminated and thus can be performed on.

That this is the case is confirmed by the following scene which continues to show Karl "auff dem Bette." He shouts after the disappearing Maria: "Halt / halt betrübter Geist!” (D 474, v. 253). Now this third scene is then performed without 
ghosts in Karl's chamber/prison. Since there is no change in location, the first two ghosts then probably perform at the back of the stage and the third ghost at the front. The disappearance of the first two ghosts is thus not a problem, since the back of the stage is simply removed from events by dimming the light and using a curtain. How the third ghost disappears is not mentioned. Since he performs at the same stage location as Karl later does, and his vanishing is mentioned explicitly, one can assume (there is, however, no real evidence) that a flying machine that allows Maria to vanish from stage is foreseen.

Let us note that in Carolus Stuardus the apparitions of ghosts are planned primarily by opening and closing the rear stage, which is possible because this activity is somewhat removed from the spectators' view, due to distance. This is most probably supplemented by implementing flying machines.

Now let us deal with Catharina von Georgien, where the flying machine is a decisive instrument, as I will illustrate shortly. With respect to scene changes, also in the normal mode of operation, this piece uses the transformation stage. In each Abhandlung the Telari have to be changed several times on the open stage. A recurring formulation in the stage directions that precede the sequence refers to this: "Der Schauplatz verändert sich in das Königl. Gemach." / "Der Schau-Platz verändert sich in den Königlichen Lustgarten.” / "Der Schau-Platz verändert sich in den Vorhoff des Palasts” etc. (D 162, D 183, D 210 et passim).

In the second Abhandlung, right in the middle of the act for once, another instruction is provided by the director: "Der SchauPlatz bildet ab den Königl. Verhör-Saal” (D 160; emphasis by MB). Since there is no explicit change in scene announced, it can be assumed that Gryphius plans to open the rear or front stage (more than likely the rear stage). ${ }^{15}$ This can also be deduced from the plot. In the previous Eingang Abas speaks with Seinelcan. The "Gesandte aus Reussen" (D 160) is subsequently announced, whose request for an

15 Unlike Flemming 1921, 170 and 180, I do not assume that in Gryphius' plays - in fact neither in Catharina nor in Carolus Stuardus - there is fundamental and constant exchange between the rear and front stage and that the most important events are situated rear stage. Moreover, I do not agree that in Catharina the formulation "der Schauplatz ändert sich in" indicates a change between the rear and front stages (compare Eggers 1967, 29, who speaks of a "bipolarity" with respect to the stage halves). To me this appears to be a violent misrepresentation of the cited sentence, which in my opinion illustrates that the stage hitherto performed on changes, regardless of whether this is the front or the rear stage. Ultimately, it does not seem certain that the sentence "der Schauplatz bildet ab" in general indicates a change in the stage set. More significant in my opinion is the issue of whether the audience realizes that a change in scene has taken place or not. Cf. the critique of Flemming by Zielske 1965, 130-132. A reference to the link between quick changes in scene and Gryphius' stage direction is also made by Müller 1967, 81. 

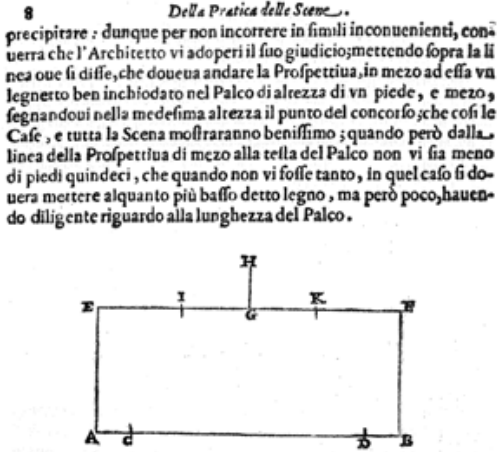

Sia la tefta del Palco A B. e la linea paralella E. F. dove deueandare la Profpertiva, il fuo mezo fia G. e fopra effovi fi ponga il legnerto G. H. che fia ben inchiodato in G. il quale fia alto vn piede,e mezo infino ad $\mathrm{H}$. \& in quella altezza fi porrá il punto del concorfo, efi potrebbe anco mettere il fudetto legnetto, e punto del concorfo in L. ouero in K. ma pare, che la più commune voglia/accióche moAri meglio) che debba partir nel mezo.

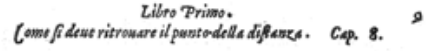

(S) I T R OVA T O, e fermato il punto del concorfo, fi do.

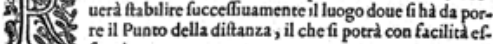
2 2.

In quefto modo; Piglieraffi vno Squadro fatto di due ftaggie fi. mile à quello che vfano li Falegnami, e Muratori, che fia giuftifimo, e ftando in mezo della Sala , $\partial$ Teatro, fi mettera $\mathrm{P}_{2}$ angolo retto dello Squadro in piano alla vifta, $\mathrm{e}$ traguarderaffi verfola tefta del Palco, anuicinandofi, d difcoftandofi fin tanto, che li raggi vifui con lilati dello Squadro vadano z̀ terminare dentro alli due fegni delle teftedlle due primecafe fi fegnara va puntonel piano della Sala, che cada perpendicolare dall'angolo dello Squadro nel detto piano, fenza però mouerlo dal luogo donde fu traguardato, e quello fard il luogo del Puato della dittanza, come per effempio.

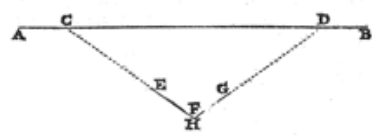

Sia la linea della tefta del Palco A. B. eli fegni delle tefte delle due prime Cafe C. D. loSquadro E. F. G. ela vilta in $\mathrm{H}$ li raggiviGuiron tuic dro F.vn fegno nel piano della Sala, che vada i piombo di quello, iui farà il luogo del Punto della diftanza.

B

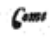

Fig. 1: Double page (pp. 8-9) from Nicola Sabbattini. Pratica di fabricar scene, e machine ne teatri. Ravenna, 1638 (reprint in Sabbattini 1926, 8-9).

audience the Shah accepts without hesitation. Thus, Abas leaves his chamber to go into the "Verhör-Saal" (D 160) where the Russian is waiting. It would seem appropriate here to be able to expand the stage in order to represent this walk adequately and theatrically.

The crucial challenge with respect to the stage lies in the first Eingang in the first Abhandlung: "Vber dem Schau-Platz oeffnet sich der Himmel / unter dem Schau-Platz die Helle. Die Ewikeit kommet von dem Himmel / und bleibet auff dem Schau-Platz stehen" (D 125). The opening of the sky is not difficult to master with theatrical means, but the opening of hell is a little more difficult. It is most likely that a lowering mechanism will be used (Fig. 1).

The great challenge I referred to, however, is the flying machine, which is required so that the allegorical salvation can come down to earth from the sky (cf. also Flemming 1921, 176). If one assumes that the beginning and end are conceived analogically, then it makes sense to speculate that the apparition of ghosts described above - and now we return to the original topic - i.e., the appearance of the dead Catharina as a spirit, will again be carried out with the flying machine.

At this point the stage directions are somewhat simple. It is merely mentioned that "Der Geist erscheinet" or "Verschwindet" (D 222). However, looking 


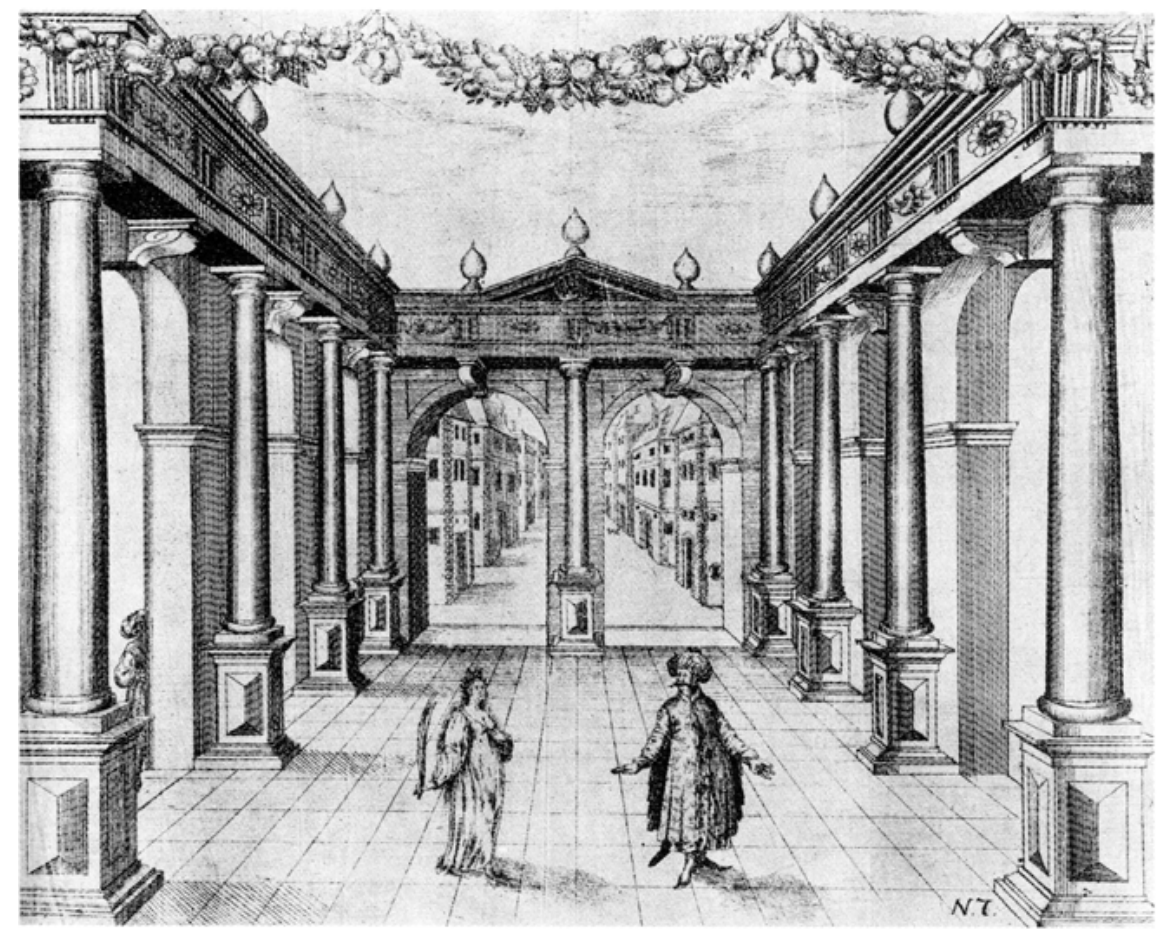

Fig. 2: Catharina von Georgien: 5th Abhandlung, final scene (Gryphius 1991, 928).

at an admittedly idealized graphical rendition of the scene (i.e., not necessarily reflecting the theater in all its technical disposition), the thesis of the second appropriation of the flying machine can certainly be further supported (Fig. 2).

Two flying machines frame the scene changes on the open stage. Through this, Catharina's exceptional position becomes apparent: with her martyrdom and death, she reaches a god-like position, and thus she herself represents a minor salvation. Consequently, she reaches a position where she can consider her situation sub specie aeternitatis. Thus, Catharina could also say, with the words of eternity (and Gryphius, who here plagiarized himself): "Was dieser baut: bricht jener Morgen ein! | Wo itzt Paläste stehn | Wird künfftig nichts als Graß und Wiese seyn” (D 126, v. 27-29). ${ }^{16}$

16 Cf. also Schings 1968, 40. It is a variation of the well-known verses from Vanitas, vanitatum, et omnia vanitas (Gryphius 1963, 7-8). 


\section{Physics of metaphysics}

Thus far the study has illustrated two results. First of all, the ghosts in Gyphius' works are, in a different way than is intended in Luther's theology, not a mouthpiece of the devil, but rather one of the divine spirit. They have the task of proclaiming future judgements with a certain performative force (whether these judgements are always appropriate is another question which can not be dealt with here). Second, for these particular apparitions of ghosts (and only for them) Gryphius draws from the entire technical repertoire available to the German Baroque stage in addition to the Telari based transformation stage, namely the flying machine as well as the lifting and lowering platforms. Benjamin's statement that the Baroque "Bühne" has its "Gott" in "der Machination" (Benjamin 1991, 261; cf. also Kaminski 1998, 118) is apparently also especially valid for ghosts.

It can thus be claimed that in the dramas of Gryphius there is a direct connection between the highest metaphysical messages and the highest achievements in theater technique. It is self-evident that the effect-oriented scenes containing ghosts were selected by Gryphius not least because they had only been possible on stage at a theater school for a short time. ${ }^{17}$ The metaphysical messages (or at least their representations) are particularly dependent on their technical feasibility.

And what is technically possible in the theater is indirectly related to the level of physical knowledge - in this case, from optics and mechanics before Newton. The changes on the Baroque stage in comparison to the Renaissance stage belong exactly to this realm: illusionary thinking is optically perfected and the mechanical movability of the stage is taken to an extreme (Brauneck 1993, Vol. II, 13-27).

Let us begin with the basics of mechanics in stagecraft: a recent study on pre-Newtonian mechanics has pointed out that in early modern times, mechanics was part of natural philosophy. Traditionally, there is a more theoretical line, which refers back to Archimedes, and a more practical one which is based on Hero of Alexandria. Beyond natural philosophy, however, there is a third line of mechanics based on the practical experience gained from the construction of machines (cf. Laird and Roux 2008, 3 and 9).

This third line of mechanics, not theoretical-practical but rather practicalpractical, is of central importance for the theater. Independent of theoretical developments in mechanics, practical knowledge on lifting machines, which originated in antiquity, has nonetheless existed since the Renaissance, regarding for instance pulleys, chains and chain gear, as well as the leverage principle. Paradigmatically,

17 On the relationship of Gryphius to the theater stage, cf. Müller 1967, 37. 
this knowledge can be identified in Leonardo da Vinci's notes (cf. Maschat 1989, 236 et passim).

This is also and specifically valid for stagecraft in the late Renaissance and Baroque periods. One can for instance recognize this in the Pratica di Fabricar Scene by the famous stage designer and architect Nicola Sabbatini. As an artist engineer, ${ }^{18}$ Sabbatini possesses fundamental knowledge in optics and mechanics, which he gained from his teacher, the mathematician Guido Ubaldo (cf. Brauneck 1993, Vol. II, 17), and also expounds in his book. This knowledge, however, is applied merely with respect to effect. As Sabbatini discusses in the last chapter of his Pratica, which addresses "Von der Leichtigkeit der Praxis," he wants exclusively to achieve "Bewunderung und Entzücken" in the audience (Sabbatini 1926, 277). Ergo: practical physics, not for theory but only for the moment of the effect.

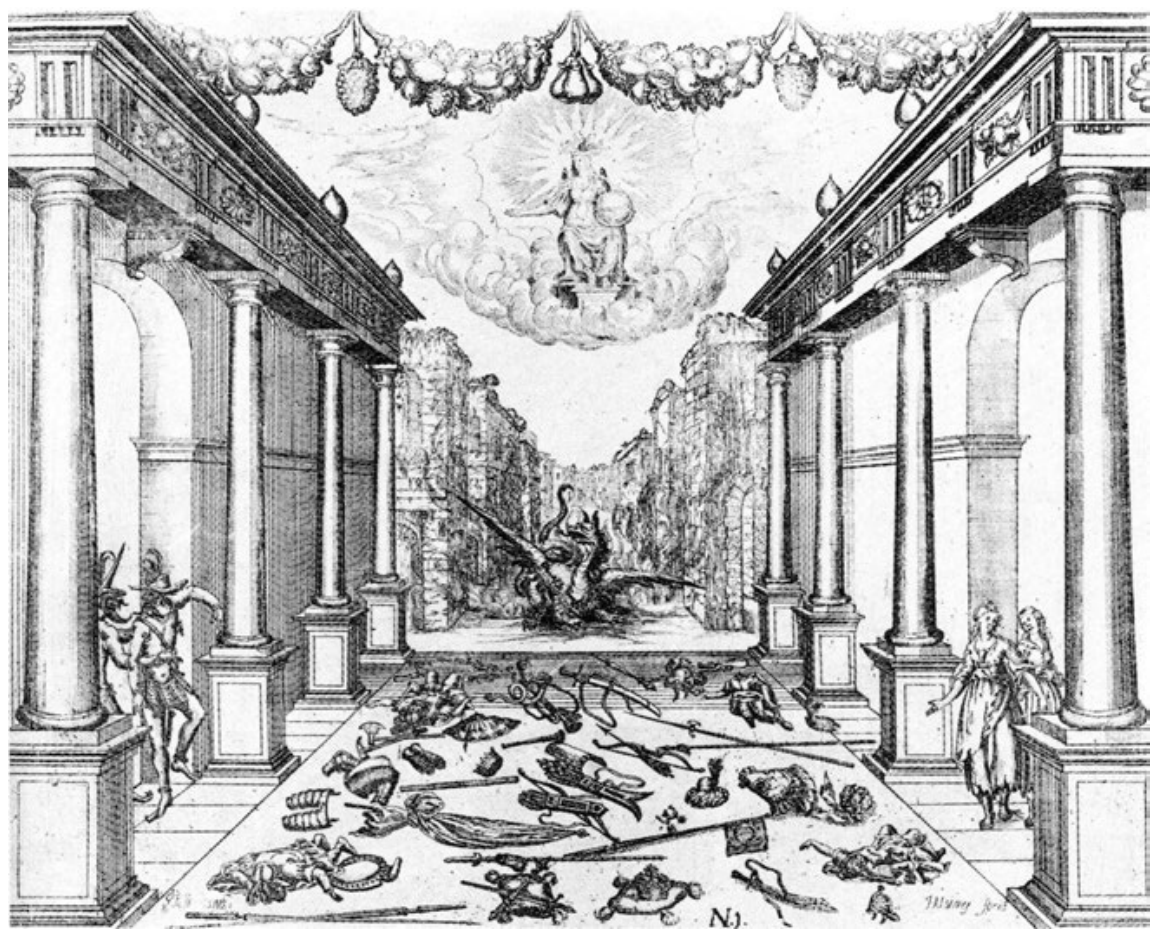

Fig. 3: Catharina von Georgien: Prologue (Gryphius 1991, 928).

18 On this concept, see Maschat 1989, 17. 
The same goes for optics as a basis of stagecraft. With the camera obscura the Renaissance developed a model of the human eye. ${ }^{19}$ And this model is further tested in the theater, and placed in the limelight in exactly that kind of theater which, as Sabbatini writes, places the "Fürsten" at the "Entfernungspunkt," as he calls it (Fig. 3) (Sabbattini 1926, 206; cf. Brauneck 2012, 133), i.e., at the particular point where the phantasmagoria, using Panofsky's words, of the "einzigen und unbewegten Auge[s]" (Panofsky 1980, 101) has its place as an outlet of perspectival presentation. The only correct perspective of the stage illusion is thus from the prince's point of view (even if the late Renaissance stage distanced itself from the principle of the central perspective for the benefit of the on-stage performance) (cf. Brauneck 1993, Vol. I, 465). The perception from the prince's seat or, in the words of Ulrike Hass, the drama of seeing (Hass 2005) - is consequently reconstructed anew in the theater.

It is not surprising in this respect if new theater technique at that time is compared to “Magie” (D’Aubignac 1971 [1715], 322; cf. also Schütz 1984, 92). In the late Renaissance and Baroque periods magic, especially the Magia naturalis or later Magia artificialis, is the realm where the great natural philosophical and metaphysical projects of the Renaissance are transferred into the technical. With his Magia naturalis Giambattista della Porta ${ }^{20}$ for instance developed an exact description of the camera obscura and subsequently a pre-Newtonian school of seeing. The same would apply to the Jesuits Kircher and Schott and their model for converting the Magia naturalis. ${ }^{21}$

The use of magic points to the fact that for authors like Porta this early form of optics - as in mechanics - was not a theory of seeing, but rather a practice of seeing, a practice which serves the purpose of creating an illusion, something to which the concept of magic refers (at least at this late point in time). A fortiori theater concerns itself not only with heaven and hell, but also and specifically with the question of how to represent heaven and "wie man eine Hölle darstellen kann" (Sabbatini 1926, 238), i.e., with effects in practice.

In order to formulate a conclusion: the contemporary practical physics mentioned here, in this case in the field of mechanics and optics, is, for literature (at least the theater), just as important, if not more so, than the theoretical physics with which authors of literary works are able to engage in discourse. The physical-technical arts of creating illusions are the performative basis for each and every reflection on theater and for the writing of texts for theater.

19 Cf. Schmitz 1981, 124, using Leonardo as an example.

20 On Porta, cf. Schmitz 1981-1995, Vol. I, 135-138.

21 On Kircher, especially his understanding of nature and technology, cf. Leinkauf 1993, 41-55. 
However, they are also helpful in developing structure for literature, since they pre-invent in a mechanical and optical manner what literature in its medium also strives toward: the art of creating illusions and the means of presenting these creations of illusions as such.

\section{Reference List}

D’Aubignac, Francois Hédelin. La pratique du théâtre und andere Schriften zur doctrine classique. Ed. Hans-Jörg Neuschäfer. Munich: Fink, 1971 [1715].

Benjamin, Walter. "Ursprung des deutschen Trauerspiels." Gesammelte Schriften. Eds. Rolf Tiedemann and Hermann Schweppenhäuser. Vol. I.3. Frankfurt a. M.: Suhrkamp, 1991.

Bergengruen, Maximilian. “'Also sind wir in Christo nur einer': 'Menschheit' als theologisches Fundament soziozentrierter Mystik (Eckhart, Tauler, Böhme).” Poetica 28 (2006): 61-90.

Bergengruen, Maximilian. "Warum Frauen mit dem Teufel schlafen, Männer hingegen mit ihm Verträge abschließen wollen: Diabolische Figurenlehre in Harsdörffers 'Schau-Plätzen.”' Dynamische Figuren: Gestalten der Zeit im Barock. Eds. Joel B. Lande and Robert Suter. Freiburg i. Br.: Rombach, 2013.

Berghaus, Günter. Die Quellen zu Andreas Gryphius' Trauerspiel “Carolus Stuardus”: Studien zur Entstehung eines historisch-politischen Märtyrerdramas der Barockzeit. Tübingen: Niemeyer, 1984.

Bogner, Ralf Georg. “Die Not der Lüge: Konfessionelle Differenzen in der Bewertung der unwahren Rede am Beispiel von Andreas Gryphius' Trauerspiel Catharina von Georgien." Daphnis 28 (1999): 595-611.

Borgstedt, Thomas. “Angst, Irrtum und Reue in der Märtyrertragödie: Andreas Gryphius' Catharina von Georgien vor dem Hintergrund von Vondels Maeghden und Corneilles Polyeucte Martyr.” Daphnis 28 (1999): 563-594.

Borgstedt, Thomas. “Andreas Gryphius, Catharina von Georgien: Poetische Sakralisierung und Horror des Politischen.” Interpretationen: Dramen vom Barock bis zur Aufklärung. Ed. Hans Pörnbacher. Stuttgart: Reclam, 2000. 37-66.

Brauneck, Manfred. Europas Theater: 2500 Jahre Geschichte - eine Einführung. Reinbek bei Hamburg: Rowohlt Taschenbuch, 2012.

Brauneck, Manfred. Die Welt als Bühne: Geschichte des europäischen Theaters. 6 vols. Stuttgart and Weimar: Metzler, 1993.

Buse, Adolf (ed.). Catechismus Romanus/Der Römische Katechismus, nach dem Beschlusse des Concils von Trient für die Pfarrer auf Befehl Papstes Pius des Fünften herausgegeben. Transl. Wilhelm Smets. Vol 1. Bielefeld and Leipzig: Velhagen and Klasing, 1867.

Campe, Rüdiger. "Theater der Institution: Gryphius' Trauerspiele Leo Armenius, Catharina von Georgien, Carolus Stuardus und Papinianus." Konfigurationen der Macht in der frühen Neuzeit. Eds. Roland Galle and Rudolf Behrens. Heidelberg: Winter, 2000. 257-287.

Eggers Werner. Wirklichkeit und Wahrheit im Trauerspiel von Andreas Gryphius. Heidelberg: Winter, 1967.

Feger, Hans. "Zeit und Angst: Gryphius Catharina von Georgien und die Weltbejahung bei Luther.” Studien zur Literatur des 17. Jahrhunderts: Gedenkschrift für Gerhard Spellerberg (1937-1996). Ed. Hans Feger. Amsterdam: Rodopi, 1997. 71-100. 
Fleming, Willi. Andreas Gryphius und die Bühne. Halle: Niemeyer, 1921.

Grimm, Reinhold. "Hugo Peter, der Ketzerchor und die Religion: Zur Deutung des Carolus

Stuardus von Gryphius." The Germanic Review 61 (1986): 3-10.

Gryphius, Andreas. Gesamtausgabe der deutschsprachigen Werke. Ed. Marian Szyrocki. Vol. I. Tübingen: Niemeyer, 1963.

Gryphius, Andreas. Dramen. Ed. Eberhard Mannack. Frankfurt a. M.: Deutscher Klassiker Verlag, 1991.

Habersetzer, Karl-Heinz. Politische Typologie und dramatisches Exemplum: Studien zum historisch-ästhetischen Horizont des barocken Trauerspiels am Beispiel von Andreas Gryphius' Carolus Stuardus und Papinianus. Stuttgart: Metzler, 1985.

Hass, Ulrike. Drama des Sehens: Auge, Blick und Bühnenform. Munich: Fink, 2005.

Kaminski, Nicola. Andreas Gryphius. Stuttgart: Reclam, 1998.

Kantorowicz, Ernst H. The King's Two Bodies: A Study in Mediaeval Political Theology. Princeton: Princeton University Press, 1997.

Laird, Walter Roy, and Sophie Roux (eds.). Mechanics and Natural Philosophy before the Scientific Revolution. Dordrecht: Springer, 2008.

Leinkauf, Thomas. Mundus combinatus: Studien zur Struktur der barocken Universalwissenschaft am Beispiel Athanasius Kirchers SJ (1602-1680). Berlin: Akademie, 1993.

Loos, Helmut. “Catharina von Georgien: Unio mystica und virtus heroica: Leitbegriffe einer Interpretation." Daphnis 28 (1999): 691-727.

Luther, Martin. Werke: Kritische Gesamtausgabe. Weimarer edition. Vol. X.2. Ed. Ulrich Köpf. Weimar: Böhlau, 1907.

Mahlmann-Bauer, Barbara. “Grimmelshausens Gespenster.” Simpliciana 26 (2004): 105-141.

Marcus Aurelius. The Meditations of the Emperor Marcus Antoninus. Ed. and Transl. Arthur

S. L. Farquharson. Vol. I. Oxford: Clarendon Press, 1944.

Maschat, Herbert. Leonardo da Vinci und die Technik der Renaissance. Munich: Profil, 1989.

McGinn, Bernard. Die Mystik im Abendland. Transl. Wolfgang Scheuermann. Freiburg i. Br.: Herder, 1996.

Müller, Othmar. Drama und Bühne in den Trauerspielen von Andreas Gryphius und Daniel Caspar von Lohenstein. Zurich: F. Gegenbauer, 1967.

Nestle, Wilhelm. "Die Fabel des Menenius Agrippa." Klio 21 (1927): 350-360.

Niefanger, Dirk. Geschichtsdrama der Frühen Neuzeit: 1495-1773. Tübingen: Niemeyer, 2005.

Neuber, Wolfgang. “Die Theologie der Geister in der Frühen Neuzeit.” Gespenster:

Erscheinungen - Medien - Theorien. Eds. Moritz Baßler, et al. Würzburg: Königshausen \& Neumann, 2005. 25-34.

Ohly, Friedrich. Hohelied-Studien: Grundzüge einer Geschichte der Hoheliedauslegung des Abendlandes bis um 1200. Wiesbaden: Steiner, 1958.

Panofsky, Erwin. “Die Perspektive als ‘symbolische Form.” Aufsätze zu Grundfragen der Kunstwissenschaft. Eds. Hariolf Oberer and Egon Verheyen. Berlin: Volker Spiess, 1980. 99-167.

Parente, James A. Religious Drama and the Humanist Tradition: Christian Theater in Germany and in the Netherlands; 1500-1680. Leiden: Brill, 1987.

Petronius. The Satyricon. Ed. and Transl. Patrick G. Walsh. Oxford: Clarendon Press, 1996.

Petronius. Satyricon reliquiae: Petronii Arbitri Satyricon Reliquiae: Satirae. Ed. Konrad Müller. 4th ed. Munich: De Gruyter, 2003. 
Porta, Conrad. Pastorale Lutheri: Das ist: Nützlicher vnd noetiger Vnterricht / von den foernemsten stuecken zum heiligen Ministerio gehoerig / Für anfahende Prediger vnd Kirchendiener zusammengebracht / Sampt einem schönen Register vnd schönen Vorrede M. Hiernonymi Mendelij / der Graffschafft Mansfelt Superintendenten. [S.I.], 1591.

Rieger, Miriam. Der Teufel im Pfarrhaus: Gespenster, Geisterglaube und Besessenheit im Luthertum der Frühen Neuzeit. Stuttgart: Steiner, 2011.

Rieks, Brigitte. Das Ehesakrament: Die Liebe christlicher Ehegatten als Analogie göttlicher Liebe. Dissertation. Munich, 1996.

Ruh, Kurt. Geschichte der abendländischen Mystik. Vol 1. Munich: C.H. Beck, 1990.

Sabbattini, Nicola. Anleitung, Dekorationen und Theatermaschinen herzustellen. Ed. and Transl. Willi Flemming. Contains a reprint of the new edition of the Italian original from 1638. Weimar: Gesellschaft der Bibliophilen, 1926.

Schings, Hans-Jürgen. “Catharina von Georgien oder bewehrete Beständigkeit.” Die Dramen des Andreas Gryphius: Eine Sammlung von Einzelinterpretationen. Ed. Gerhard Kaiser. Stuttgart: Metzler, 1968. 35-72.

Schmitz, Emil-Heinz. Handbuch zur Geschichte der Optik. Vol. I. Bonn [i.a.]: J. P. Wayenborgh 1981.

Schott, Caspar. Physica curiosa Aucta \& Correcta, sive Mirabilia Naturae et Artis. Würzburg: Hertz, 1667.

Schöne, Albrecht. “Ermordete Majestät Oder Carolus Stuardus König von Groß Britannien.” Die Dramen des Andreas Gryphius: Eine Sammlung von Einzelinterpretationen. Ed. Gerhard Kaiser. Stuttgart: Metzler, 1968. 117-169.

Schönle, Gustav. Das Trauerspiel Carolus Stuardus des Andreas Gryphius: Quellen und Gestaltung des Stoffes. Dissertation. Cologne, 1933.

Schütz, Heinz. Barocktheater und Illusion. Dissertation. Munich, 1982. Frankfurt a. M.: Lang, 1984.

Spellerberg, Gerhard. “Narratio im Drama oder der politische Gehalt eines 'Märtyrerstückes:' Zur Catharina von Georgien des Andreas Gryphius." Wahrheit und Wort: Festschrift für Rolf Tarot zum 65. Geburtstag. Eds. Gabriela Scherer and Beatrice Wehrli. Bern: Lang, 1996. 437-461.

Stackhouse, Janifer G. The Constructive Art of Gryphius' Historical Tragedies. Bern: Lang, 1986. Streller, Siegfried. "Staats- und Rechtsauffassung Andreas Gryphius' in Carolus Stuardus und Aemilius Paulus Papianus." Andreas Gryphius: Weltgeschick und Lebenszeit: Ein schlesischer Barockdichter aus deutscher und polnischer Sicht. Ed. Stiftung GerhartHauptmann-Haus. Düsseldorf: Droste, 1993. 109-124.

Steinhagen, Harald. Wirklichkeit und Handeln im barocken Drama: Historisch-ästhetische Studien zum Trauerspiel des Andreas Gryphius. Tübingen: Niemeyer, 1977.

Szarota, Elida Maria. Geschichte Politik und Gesellschaft im Drama des 17. Jahrhunderts. Bern: Francke, 1976.

Tarot, Rolf. "Recht und Unrecht im barocken Trauerspiel, am Beispiel des Carolus Stuardus von Andreas Gryphius.” Simpliciana 9 (1987): 215-237.

Zielske, Harald. Handlungsort und Bühnenbild im 17. Jahrhundert: Untersuchungen zur Raumdarstellung im europäischen Barocktheater. Dissertation. Munich, 1965. 
